\title{
Geography Literacy Profile of Pre-Service Teachers: The Case of Turkey
}

\author{
Ebru Gençtürk Güven ${ }^{1}$ \\ ${ }^{1}$ Fatih Education Faculty, Trabzon University, Trabzon, Turkey \\ Correspondence: Ebru Gençtürk Güven, Fatih Education Faculty, Trabzon University, Trabzon, Turkey.
}

Received: June 15, 2021

Accepted: October 11, $2021 \quad$ Online Published: November 26, 2021

doi:10.5539/ies.v14n12p125

URL: https://doi.org/10.5539/ies.v14n12p125

\begin{abstract}
The study aims to determine the "Geography Literacy" levels of senior year pre-service teachers. To do so, the correlations between geo-literacy on the one hand, and the program the student is enrolled in, the type of settlement the student lived in during secondary education, the type of high school the student graduated from, the student's travel experience so far, and attitudes towards geography on the other, were assessed. The study was carried out with 4th year pre-service teachers $(\mathrm{n}=427)$ enrolled in six programs in the faculty of education, during the fall semester of academic year 2018-2019. The "Geography Literacy Test" developed by Gençtürk (2009) was used as the data collection tool. The data gathered were analyzed through descriptive, independent samples t-test, one-way ANOVA, chi-square, and Pearson correlation techniques. The study revealed that the geo-literacy levels of pre-service teachers were inadequate. Moreover, the geography literacy levels were found to exhibit significant variance with reference to gender, attitudes, the type of high school, the program the student is enrolled in, and the type of settlement the student lived in during secondary education. The findings were then used as the basis of specific proposals for increasing geo-literacy levels and paving the way for future studies.
\end{abstract}

Keywords: geography literacy, pre-service teachers, teacher qualifications

\section{Introduction}

A number of environmental factors affect our daily life. Yet, one is often unaware of the place geography occupies in our life, and is inclined to think that geographic information can be gained through formal processes. As a science, geography instills more than general knowledge. It also helps the development of scientific thought by helping establish connections between the person and the environment, and contributes to the growth of one's bonds to the homeland (Doğanay, 2002). Moreover, geographic information is a prerequisite for questions based on geography (e.g. what, where, when) in the context of national and international decision-making, achieving sustainable development in theory as well as practice, and raising "geographical awareness" in general. Geography and geographic knowledge are valuable due to their connection with the problems of the world we live in, as such knowledge teaches the students how to read maps and how to interpret local and global knowledge, thus developing their critical thinking skills, helping them understand the world better. Therefore, geography should be the central axis of life, if one is to have geographical thinking skills (Thomas, 2001). Geographic knowledge plays an important part in enabling individuals develop a spatial as well as cultural perception of the world, starting with one's immediate circle, followed by the development of ideas and projects about the environment one lives in. Students who have a strong grasp of geographic knowledge have an advantage in terms of growing into leaders for their countries who will subsequently make the decisions for optimal use of national resources. The location of natural resources, the structure of transportation networks, industrialization, energy generation, and other geographic factors all shape the economy a country or region. Moreover, geographic knowledge's importance in terms of protecting natural environment, which is crucial for human life, cannot be overstated. Geographic knowledge and associated information is used especially for identifying the effects of environmental factors on human behavior, defining the ways through which humans change the environment they live in, and assessing long-term environmental effects of social processes such as population increase and technological development. The use of that information, in turn, requires geography literacy. In parallel to the increasing importance of geographic information, studies on "geo-literacy" concept saw increasing attention, with a focus on the need to raise individuals with geo-literacy skills. The studies also revealed the fact that the students and pre-service teachers in various stages of education lack the knowledge and competences they need with respect to the physical 
and human environment. Moreover, students were also found lacking in terms of higher-level cognitive skills associated with geography (Bein, 1990, 2009; Bunnin, 2001; Cross, 1987; Chiodo, 1993; Donovan, 1993; Eve et al., 1994; Hardwick et al., 2000; NAEP, 1994; National Geographic Roper Survey, 2002; National Geographic Roper Survey, 2006; Nolan, 2002; Oigara, 2006; Roger, 1997; Saarinen \& MacCabe, 1995; Schoenfeldt, 2001; Sievertson, 2005; Thomas, 2001; Torrens, 2001; Tuncel, 2002; Winship, 2004; Wood et al., 1988; Trygestad, 1997).

Acts of terror all around the world, global climate change, not to mention natural and man-made disasters such as air pollution drive interest in and sensitivity about places beyond the borders of one's own country, underlining the need for individuals with geographic literacy (Chapin, 2009). Locations are rather meaningless and irrelevant for people who lack geographic literacy (Gritzner, 2003). In this context, the need for geographic information and awareness for achieving sustainable development is apparent. Such awareness, on the other hand, can be produced through robust geography education at all levels of education, starting with preschool (Doğanay, 2002; Karabağ, 2001; Karabağ \& Şahin, 2007; Gritzner, 2003; Şahin, 2003; Marran, 1992).

Today, globalization is mentioned in almost all contexts. Naturally, the education system is also affected by developments on that front. Globalization, in a sense, forced people and countries to get a better geographic understanding of each other. The result was the need to educate individuals so as to ensure that they meet the requirements of "Global Citizenship" and "geography literacy". Against this background, the present study aims to assess the geo-literacy levels of pre-service teachers enrolled in various teacher-training programs, based on the foundations established in the literature on the importance of geographic information and teacher competences. In this context, the following research questions were investigated:

1) Do the pre-service teachers have the skills to locate the countries neighboring Turkey?

2) Do the scores pre-service teachers got in the "Geo-Literacy Test" vary significantly with reference to:

2.1) Gender?

2.2) Type of program they are enrolled in?

2.3) Type of high school they had graduated from?

2.4) Type of settlement they lived during their secondary education?

2.5) The number of provinces they had travelled to?

2.6) Their attitudes towards geography?

\section{Method}

The study is based on what the literature labels "Descriptive Method" or "Survey Research". Quantitative studies in education sciences often use descriptive survey models (Cohen \& Manion, 2007). For, most problems regarding education are descriptive in essence, and it is often noted that progress towards high-level studies is not possible without robust description in place in the first hand. That is why descriptive studies are considered as imperative building blocks for more detailed studies to follow (Balc1, 2001). This kind of studies are designed to express, interpret, analyze, categorize, compare, and define the existing state of affairs of a given group at a given time or place, with respect to the research problem (Cohen \& Manion, 2007). Survey models work with a sample of the universe, in order to come up with quantitative descriptions and definitions of the ideas, attitudes, and inclinations of the universe. Furthermore, the results reached with reference to the sample can then be used for generalizations by the researcher, in an effort to come up with judgments regarding the universe (Creswell, 2003; Gray, 2004). However, they are very complicated to implement. Robust survey studies begin with a review of the theoretical framework, and proceed with detailed and extensive work planned in advance, for the whole process to culminate in the analysis and interpretation of data (Hutchinson, 2004).

\subsection{Data Collection Tool}

The geography literacy test developed by Gençtürk (2009), based on a review of other tests available in the literature, is comprised of 64 questions covering 5 sub-dimensions. The development of the test was based on an analysis of the other scales available to date, and saw the incorporation of some questions from existing sources, with the permission of original authors thereof. The test was also subjected to validity and reliability analyses, leading to an average power rating of .48, alpha reliability factor of .88, average score of 41.7 , standard deviation of 10.5, and series width of 52. Moreover, to test the homogeneity of the instrument, data obtained in the pilot stage were fed into SPSS 21 software. Pearson correlation coefficient was calculated to assess the level of correlation between the scores obtained from the whole test as well as its sub-dimensions. The results are presented in the following table. 
Table 1. Pearson correlation coefficient values regarding the homogeneity of the geo-literacy test

\begin{tabular}{lccccc}
\hline Correlation & 1 & 2 & 3 & 4 & 5 \\
\hline 1. Location & 1.00 & & & & \\
2. Physical Systems & $.60^{* *}$ & 1.00 & & & \\
3. Human Systems & $.48^{* *}$ & $.51^{* *}$ & 1.00 & & \\
4. Global Connections & $.47^{* *}$ & $.46^{* *}$ & $.47^{* *}$ & 1.00 & \\
5. Environment & $.39^{* *}$ & $.43^{* *}$ & $.42^{* *}$ & $.48^{* *}$ & 1.00 \\
\hline
\end{tabular}

$* * \mathrm{p}=.001$ (two-way)

Table 1 presents the level of correlation between the analysis tool as a whole and its sub-dimensions. Medium and high levels of positive and significant correlation are found between the scale as a whole, and its sub-dimensions. Therefore, one can forcefully argue that the scale and its sub-dimensions are capable of assessing the competence covered, and the scale is considered have structural validity in terms of the criteria involved (Gençtürk, 2009).

\subsection{Data Analysis}

Obtained data were analyzed using SPSS 21. In the data analysis frequency, percent, mean, Pearson correlation, Chi-Squared were used. At the same time this study was used Shapiro-Wilk test as normality test. Obtained p value $(p>0.5)$ showed that the data were normally distributed. So parametric tests (unpaired sample t-test, one way ANOVA ) were used in the analysis of the data.

\subsection{Sampling Process}

The study is carried out with 427 pre-service teachers enrolled in the senior year of various programs in the Faculty of Education of Trabzon University during the academic year 2018-2019. Convenience sampling was used, and the study was carried out with volunteers. Data about the participants are presented in Table 2.

Table 2. Sample Group

\begin{tabular}{|c|c|c|c|c|}
\hline Personal Details & & $\mathrm{f}$ & $\%$ & Total \\
\hline \multirow{2}{*}{ Gender } & Male & 152 & 35.6 & \multirow{2}{*}{427} \\
\hline & Female & 275 & 64.4 & \\
\hline \multirow{5}{*}{ Program } & Primary school & 96 & 22.5 & \multirow{5}{*}{427} \\
\hline & Preschool & 68 & 15.9 & \\
\hline & Mathematics & 56 & 13.1 & \\
\hline & Turkish & 80 & 18.7 & \\
\hline & Guidance counseling & 66 & 15.5 & \\
\hline \multirow{5}{*}{ Type of High School } & CEIT & 61 & 14.3 & \multirow{5}{*}{427} \\
\hline & Ordinary High School & 122 & 28.6 & \\
\hline & Anatolian High School & 171 & 40 & \\
\hline & Vocational High School & 53 & 12.4 & \\
\hline & Other & 81 & 19 & \\
\hline \multirow{5}{*}{ Number of Provinces Visited } & $1-10$ & 264 & 61.8 & \multirow{5}{*}{427} \\
\hline & $11-20$ & 112 & 26.2 & \\
\hline & $21-30$ & 25 & 5.9 & \\
\hline & $31-+$ & 21 & 4.9 & \\
\hline & None & 5 & 1.2 & \\
\hline
\end{tabular}

\section{Findings}

This section presents the data gathered through the sketch map activity to assess the ability to locate the neighbors of Turkey. Then comes an analysis of the average scores achieved through the Geo-Literacy Scale, presented in tables.

\subsection{Findings on the Ability to Locate the Neighbors of Turkey}

The following table shows the results of the unpaired t-test to see whether the pre-service teachers' ability to locate Turkey's neighbors vary with reference to gender or not. 
Table 3. Results of the unpaired t-test for the gender variable's effects on the locating skill

\begin{tabular}{ccccccc}
\hline Groups & $\mathrm{N}$ & Average & $\mathrm{S}$ & $\mathrm{sd}$ & $\mathrm{t}$ & $\mathrm{P}$ \\
\hline Male & 152 & 6.76 & 1.97 & \multirow{2}{*}{425} & 4.26 & .000 \\
Female & 275 & 5.72 & 2.35 & & & \\
\hline
\end{tabular}

The review of Table 3 reveals that gender leads to a significant difference in the pre-service teachers' scores regarding the locating skills. Accordingly, male $(\overline{\mathrm{x}}=6.76)$ pre-service teachers were found to be more successful compared to their female $(\overline{\mathrm{X}}=5.72)$ peers in pointing out Turkey's neighbors on a map.

Chi-squared test was applied to see whether a significant relationship exists between the higher education programs the pre-service teachers are enrolled in and their average scores regarding the locating skills. The results and the cross-correlations are presented in the following table.

Table 4. Results of the chi-squared analysis of the scores pre-service teachers received in the sketch map test, with reference to the programs they are enrolled in

\begin{tabular}{llllllllllll}
\hline & \multicolumn{8}{c}{ Number of instances and rate of accurately locating Turkey's neighbors } \\
\hline Programs & & 0 & 1 & 2 & 3 & 4 & 5 & 6 & 7 & 8 & Total \\
\hline \multirow{2}{*}{ Primary school } & $\mathrm{F}$ & - & - & 2 & - & 6 & 4 & 21 & 7 & 56 & 96 \\
& $\%$ & - & - & 2.1 & - & 6.2 & 4.2 & 21.9 & 7.3 & 58.3 & 22.5 \\
\hline \multirow{2}{*}{ Preschool } & $\mathrm{F}$ & 12 & 3 & 4 & 6 & 7 & 14 & 9 & 9 & 4 & 68 \\
& $\%$ & 17.6 & 4.4 & 5.9 & 8.8 & 10.3 & 20.6 & 13.2 & 13.2 & 5.9 & 15.9 \\
\hline \multirow{2}{*}{ Mathematics } & $\mathrm{F}$ & 1 & 1 & - & - & 1 & 2 & 12 & 1 & 38 & 56 \\
& $\%$ & 1.8 & 1.8 & - & - & 1.8 & 3.6 & 21.4 & 1.8 & 67.9 & 13.1 \\
\hline \multirow{2}{*}{ Turkish } & $\mathrm{F}$ & 1 & 1 & 1 & 1 & 6 & 8 & 12 & 7 & 43 & 80 \\
& $\%$ & 1.2 & 1.8 & 1.2 & 1.2 & 7.5 & 10 & 15 & 8.8 & 53.8 & 18.7 \\
\hline \multirow{2}{*}{ Guidance counseling } & $\mathrm{F}$ & 5 & 1 & 4 & 5 & 7 & 7 & 9 & 10 & 18 & 66 \\
& $\%$ & 7.6 & 1.5 & 6.1 & 7.6 & 10.6 & 10.6 & 13.6 & 15.2 & 27.3 & 15.5 \\
\hline \multirow{2}{*}{ CEIT } & $\mathrm{F}$ & 3 & 1 & - & 2 & 6 & 5 & 10 & 16 & 18 & 61 \\
& $\%$ & 4.9 & 1.5 & - & 3.3 & 9.8 & 8.2 & 16.4 & 26.2 & 29.5 & 14.3 \\
\hline \multirow{2}{*}{ Grand Total } & $\mathrm{F}$ & 22 & 7 & 11 & 14 & 33 & 40 & 73 & 50 & 177 & 427 \\
& $\%$ & 5.2 & 1.6 & 2.6 & 3.3 & 7.7 & 9.4 & 17.1 & 11.7 & 41.5 & 100 \\
\hline
\end{tabular}

$\mathrm{X}^{2}=1.460 ; \overline{\mathrm{sd}}=40 ; \mathrm{P}=.000$.

The review of Table 4 reveals significant variation in pre-service teachers' ability to accurately locate Turkey's neighbors $\left(\mathrm{X}_{(40)}^{2}=1.460, \mathrm{p}<.05\right)$, with reference to the program they are enrolled in. Overall, $41.5 \%$ of pre-service teachers are able to accurately locate Turkey's eight neighbors on the map, whereas $20 \%$ were able to locate five or less neighbors. The highest level of success in terms of accurately locating Turkey's neighbors on the map was achieved by pre-service teachers enrolled in Mathematics Teacher Training program (67.9\%), followed by those enrolled in Primary School Teacher Training (58.3\%) and Turkish Teacher Training (53.8\%) programs. The lowest rate of success in terms of accurately locating Turkey's neighbors on the map, on the other hand, was registered with the pre-service teachers enrolled in the Preschool Teacher Training program (5.9\%). Pre-service teachers enrolled in the Guidance Counselor Training (27.3\%) and Computer Education and Instructional Technologies (CEIT) (29.5\%) programs achieved comparable rates. The success achieved by pre-service mathematics teachers is noteworthy in this context.

Chi-squared test was applied to see which neighbors of Turkey saw the highest / lowest rates of success in terms of being located on the map. The results are presented in a crosstab. The data regarding the rates of accurate locating of individual neighbors of Turkey are presented in Table 5. 
Table 5. Chi-Square test results on the pre-service teachers' rates of accurately locating turkey's neighbors on a map, with reference to the programs they are enrolled in

\begin{tabular}{|c|c|c|c|c|c|c|c|c|c|c|c|c|}
\hline \multicolumn{3}{|c|}{ Program } & \multicolumn{8}{|c|}{ Neighbors } & \multicolumn{2}{|c|}{$\begin{array}{c}\text { Program's } \\
\text { Overall Score }\end{array}$} \\
\hline & & & \multirow{2}{*}{$\begin{array}{c}\text { GEO } \\
90 \\
\end{array}$} & \multirow{2}{*}{$\begin{array}{c}\text { ARM } \\
72 \\
\end{array}$} & \multirow{2}{*}{$\begin{array}{c}\text { AZE } \\
85 \\
\end{array}$} & \multirow{2}{*}{$\begin{array}{c}\text { IRN } \\
80 \\
\end{array}$} & \multirow{2}{*}{$\begin{array}{c}\text { IRQ } \\
85 \\
\end{array}$} & \multirow{2}{*}{$\begin{array}{c}\text { SYR } \\
91\end{array}$} & \multirow{2}{*}{$\begin{array}{c}\text { GRE } \\
85 \\
\end{array}$} & \multirow{2}{*}{$\begin{array}{c}\text { BUL } \\
83 \\
\end{array}$} & $\mathrm{~F}$ & \multirow{2}{*}{$\%$} \\
\hline 8 & $\mathrm{C}$ & $\mathrm{F}$ & & & & & & & & & \multirow{4}{*}{96} & \\
\hline $\begin{array}{l}\dot{J} \\
0 \\
\lambda\end{array}$ & C & $\%$ & 93.8 & 75 & 88.5 & 83.3 & 88.5 & 94.8 & 88.5 & 86.5 & & \multirow{3}{*}{22.5} \\
\hline$\widehat{\tilde{E}}$ & W & $\mathrm{F}$ & 6 & 24 & 11 & 16 & 11 & 5 & 11 & 13 & & \\
\hline$\equiv$ & 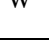 & $\%$ & 6.2 & 25 & 11.5 & 16.7 & 11.5 & 5.2 & 11.5 & 13.5 & & \\
\hline \multirow{4}{*}{ 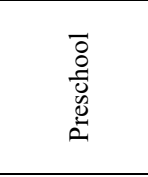 } & \multirow{2}{*}{$\mathrm{C}$} & $\mathrm{F}$ & 52 & 9 & 28 & 32 & 37 & 49 & 33 & 36 & \multirow{4}{*}{68} & \multirow{4}{*}{15.9} \\
\hline & & $\%$ & 76.5 & 13.2 & 41.2 & 47.1 & 54.4 & 72.1 & 48.5 & 52.9 & & \\
\hline & \multirow{2}{*}{ W } & $\mathrm{F}$ & 16 & 59 & 40 & 36 & 31 & 19 & 35 & 32 & & \\
\hline & & $\%$ & 23.5 & 86.8 & 58.8 & 52.9 & 45.6 & 27.9 & 51.5 & 47.1 & & \\
\hline \multirow{4}{*}{ 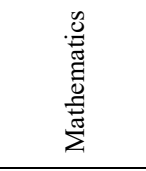 } & \multirow{2}{*}{$\mathrm{C}$} & $\mathrm{F}$ & 54 & 46 & 50 & 52 & 53 & 53 & 44 & 45 & \multirow{4}{*}{56} & \multirow{4}{*}{13.1} \\
\hline & & $\%$ & 96.4 & 82.1 & 89.3 & 92.9 & 94.6 & 94.6 & 78.6 & 80.4 & & \\
\hline & \multirow{2}{*}{ W } & $\mathrm{F}$ & 2 & 10 & 6 & 4 & 3 & 3 & 12 & 11 & & \\
\hline & & $\%$ & 3.6 & 17.9 & 10.7 & 7.1 & 5.4 & 5.4 & 21.4 & 19.6 & & \\
\hline \multirow{4}{*}{ 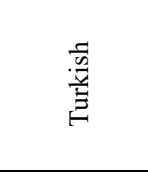 } & $\mathrm{C}$ & $\mathrm{F}$ & 78 & 46 & 66 & 63 & 72 & 72 & 69 & 69 & & \\
\hline & C & $\%$ & 97.5 & 57.5 & 82.5 & 78.8 & 90 & 90 & 86.2 & 86.2 & 80 & 187 \\
\hline & W & $\mathrm{F}$ & 2 & 34 & 14 & 17 & 8 & 8 & 11 & 11 & 80 & 10.1 \\
\hline & w & $\%$ & 2.5 & 42.5 & 17.5 & 21.2 & 10 & 10 & 13.8 & 13.8 & & \\
\hline & $\mathrm{C}$ & $\mathrm{F}$ & 53 & 32 & 39 & 42 & 51 & 55 & 41 & 42 & & \\
\hline 寻 & & $\%$ & 80.3 & 48.5 & 59.1 & 63.6 & 77.3 & 83.3 & 62.1 & 63.6 & 66 & 15.5 \\
\hline 胥 & W & $\mathrm{F}$ & 13 & 34 & 27 & 24 & 15 & 11 & 25 & 24 & & \\
\hline & $\mathrm{w}$ & $\%$ & 19.7 & 51.5 & 40.9 & 36.4 & 22.7 & 16.7 & 37.9 & 36.4 & & \\
\hline & $C$ & $\mathrm{~F}$ & 46 & 32 & 46 & 44 & 47 & 55 & 52 & 49 & & \\
\hline 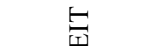 & C & $\%$ & 75.4 & 52.5 & 75.4 & 72.1 & 77 & 90.2 & 85.2 & 80.3 & 61 & 143 \\
\hline$\vec{U}$ & $\mathrm{~W}$ & $\mathrm{~F}$ & 15 & 29 & 15 & 17 & 14 & 6 & 9 & 12 & 01 & 14.3 \\
\hline & $\mathrm{w}$ & $\%$ & 24.6 & 47.5 & 24.6 & 27.9 & 23 & 9.8 & 14.8 & 19.7 & & \\
\hline & $\mathrm{C}$ & $\mathrm{F}$ & 373 & 237 & 314 & 313 & 345 & 375 & 324 & 324 & & \\
\hline Grand Total & c & $\%$ & 87.4 & 55.5 & 73.5 & 73.3 & 80.8 & 87.8 & 75.9 & 75.9 & 42 & 100 \\
\hline Urand lotal & W & $\mathrm{F}$ & 54 & 190 & 113 & 114 & 82 & 52 & 103 & 103 & 7 & 100 \\
\hline & w & $\%$ & 12.6 & 44.5 & 26.5 & 26.7 & 19.2 & 12.2 & 24.1 & 24.1 & & \\
\hline & & & $\mathrm{X}^{2}: 33.3$ & $\mathrm{X}^{2}: 81.7$ & $X^{2}: 65.3$ & $X^{2}: 44.2$ & $X^{2}: 46.5$ & $X^{2}: 24.5$ & $X^{2}: 50.8$ & $X^{2}: 43.5$ & & \\
\hline Chi-s & are $(1$ & & 23 & 33 & 26 & 16 & 88 & 06 & 72 & 02 & & \\
\hline & & & $\mathrm{P}=.000$ & $\mathrm{P}=.000$ & $\mathrm{P}=.000$ & $\mathrm{P}=.000$ & $\mathrm{P}=.000$ & $\mathrm{P}=.000$ & $\mathrm{P}=.000$ & $\mathrm{P}=.000$ & & \\
\hline
\end{tabular}

${ }^{*} \mathrm{C}=$ Those pointing out the correct location; ${ }^{*} \mathrm{~W}=$ Those failing to point out the correct location.

The results of the chi-squared analysis presented in the table reveals significant variation $(\mathrm{p}<.05)$ in rates of success in locating each and every one of the eight neighbors of Turkey, with reference to the programs the participants are enrolled in. The highest rates of awareness about individual neighbors of Turkey among pre-service teachers are registered with Syria $(87.8 \%)$, Georgia $(87.4 \%)$, and Iraq $(80.8 \%)$. On the other hand, Armenia (55.5\%) stands out as the neighbor the location of which is least well-known, while Bulgaria and Greece (75.9\%) and Iran and Azerbaijan (Nakhchivan) (73\%) saw equal levels of awareness among pre-service teachers in terms of their locations. Table 5 also revealed that pre-service teachers enrolled in all programs covered had difficulty in locating Turkey's neighbors at a rate of approximately $20-25 \%$, peaking at an inaccuracy rate of $44.5 \%$ in the case of Armenia, Georgia (12.6\%) and Syria (12.2\%) stood out as exceptions.

\subsection{Findings Regarding the Average Geography Literacy Test Scores}

The findings reached are presented with reference to the variables investigated in the study.

The results of the unpaired sample t-test on whether gender caused a significant variation in geo-literacy levels of pre-service teachers are presented in Table 6. 
Table 6. Results of the unpaired sample t-test regarding the pre-service teachers' geo-literacy levels with reference to gender

\begin{tabular}{ccccccc}
\hline Groups & $\mathrm{N}$ & Average & $\mathrm{S}$ & $\mathrm{Sd}$ & $\mathrm{T}$ & $\mathrm{P}$ \\
\hline Male & 152 & 12.69 & 5.45 & & & \\
Female & 275 & 9.49 & 4.49 & & 6.52 & .000 \\
\hline
\end{tabular}

Table 6 reveals that gender leads to a significant difference in geo-literacy levels of pre-service teachers $\left[\mathrm{t}_{(425)}=\right.$ $6.52, \mathrm{p}<.000]$. The participants' arithmetic average geo-literacy scores reveal higher levels of literacy for males $(\mathrm{X}=12.69)$ compared to females $(\mathrm{X}=9.49)$.

One-way ANOVA is applied to determine if any variation of the geo-literacy levels of the participants occurred with reference to the programs they are enrolled in. The findings are presented in Tables 7 and 8.

Table 7. Descriptive findings regarding the pre-service teachers' geo-literacy levels with reference to the programs they are enrolled in

\begin{tabular}{cccccc}
\hline Programs & $\mathrm{N}$ & Average & Std. Dev. & Min. & Max. \\
\hline Primary school & 96 & 11.57 & 4.32312 & 2.00 & 22.00 \\
Preschool & 68 & 8.13 & 4.08822 & .00 & 24.00 \\
Mathematics & 56 & 10.14 & 5.84474 & 2.00 & 24.00 \\
Turkish & 80 & 13.00 & 4.63340 & 2.00 & 24.00 \\
Guidance counseling & 66 & 10.81 & 5.27960 & 1.00 & 24.00 \\
CEIT & 61 & 8.77 & 3.96398 & .00 & 19.00 \\
Total & 427 & 10.58 & 4.94321 & .00 & 24.00 \\
\hline
\end{tabular}

According to the data presented in Table 7, the highest average scores the pre-service teachers got in the geo-literacy test were achieved by those enrolled in Turkish Teacher Training Program $(\mathrm{X}=13.00)$. The pre-service teachers enrolled in the Primary School, Mathematics, and Turkish Teacher Training Programs received scores in 2-24 range, while their peers enrolled in the Preschool Teacher Training Program, CEIT Program, and Guidance Counseling Program got scores in 0-24, 0-19, and 1-24 ranges respectively.

The results of the one way analysis of variance applied to see if any statistically significant variation exists with respect to the pre-service teachers' geo-literacy levels with reference to the programs they are enrolled in are presented in Table 8 .

Table 8. One-way anova findings regarding the pre-service teachers' geo-literacy levels with reference to the programs they are enrolled in

\begin{tabular}{cccccc}
\hline Source of variance & KT & Sd & KO & F & P \\
\hline Between groups & 1184.696 & 5 & 236.939 & & \\
Within groups & 9224.761 & 421 & 21.912 & & .000 \\
Total & 10409.457 & 426 & & & \\
\hline
\end{tabular}

Table 8 reveals, in the light of the F-test, that the programs the pre-service teachers are enrolled in led to significant variation in their geo-literacy levels $\left[\mathrm{F}_{(5.421)}=10.813, \mathrm{p}<.05\right]$. The results of the multiple comparisons Tukey HSD analysis regarding such variation are provided in Table 9. 
Table 9. Results of Tukey HSD (Post-Hoc Test) regarding the pre-service teachers' geo-literacy levels with reference to the programs they are enrolled in

\begin{tabular}{cccc}
\hline \multirow{2}{*}{ (I) Program } & (J) Program & Mean variation & Sig. \\
& Preschool & $(\mathrm{I}-\mathrm{J})$ & .000 \\
\multirow{2}{*}{ Primary school } & CEIT & $3.44056^{*}$ & .004 \\
& Primary school & $2.80242^{*}$ & .000 \\
\multirow{2}{*}{ Preschool } & Turkish & $-3.44056^{*}$ & .000 \\
& Guidance counseling & $-4.86765^{*}$ & .012 \\
\hline Mathematics & Turkish & $-2.68583^{*}$ & .007 \\
\hline \multirow{2}{*}{ Turkish } & Preschool & $-2.85714^{*}$ & .000 \\
& Mathematics & $4.86765^{*}$ & .007 \\
\hline \multirow{2}{*}{ Guidance counseling } & CEIT & $2.85714^{*}$ & .002 \\
\hline \multirow{2}{*}{ CEIT } & Preschool & $4.22951^{*}$ & .012 \\
& Primary school & $2.68583^{*}$ & .004 \\
& Turkish & $-2.80242^{*}$ & .000 \\
\hline
\end{tabular}

The comparison provided in Table 9 reveals that the geo-literacy scores of pre-service Primary School teachers were higher than those of their peers enrolled in Preschool and CEIT teacher training programs, that the scores of pre-service Preschool teachers were lower than those of their peers enrolled in Primary School and Turkish Teacher Training and Guidance Counseling programs, that the scores of the pre-service Mathematics teachers were lower than those of their peers enrolled in the Turkish Teacher Training program, that the scores of the pre-service Turkish teachers were higher than those of their peers enrolled in Preschool, Mathematics and CEIT teacher training programs, that the scores of the pre-service Guidance Counselors were higher than those of their peers enrolled in the Preschool teacher training program, that the scores of the pre-service CEIT teachers were lower than those of their peers enrolled in the Primary School and Turkish teacher training programs, and that all such differences were significant $(\mathrm{p}<.05)$.

The results of the descriptive analysis and one-way ANOVA to show the variance, if any, in mean scores pre-service teachers got in the Geo-Literacy Test with reference to the type of high school they graduated from are presented in Tables 10 and 11.

Table 10. Descriptive statistics findings regarding the pre-service teachers' geo-literacy levels with reference to the type of high school they graduated from

\begin{tabular}{cccccc}
\hline Type of High School & $\mathrm{N}$ & Average & Std. Dev. & Min. & Max. \\
\hline Ordinary High School & 122 & 10.7541 & 4.88430 & .00 & 24.00 \\
Anatolian High School & 171 & 10.8596 & 4.75062 & .00 & 22.00 \\
Vocational High School & 53 & 8.5283 & 3.99328 & 2.00 & 19.00 \\
Other & 81 & 11.1111 & 5.69430 & 3.00 & 24.00 \\
Total & 427 & 10.58 & 4.94321 & .00 & 24.00 \\
\hline
\end{tabular}

According to Table 10, the mean score pre-service teachers who graduated from an ordinary high school got in the geo-literacy test was $X=10.75$, in comparison to the mean scores of their peers who had graduated from an Anatolian high school $(X=10.85)$, and their peers who had graduated from vocational high schools $(X=8.52)$.

Table 11. One-way anova findings regarding the pre-service teachers' geo-literacy levels with reference to the type of high school they had graduated from

\begin{tabular}{cccccc}
\hline Source of variance & KT & Sd & KO & F & P \\
\hline Between groups & 262.995 & 3 & 87.665 & & \\
Within groups & 10146.462 & 423 & 23.987 & 3.655 & .013 \\
Total & 10409.457 & 426 & & & \\
\hline
\end{tabular}

The variance analysis applied reveals that the average scores pre-service teachers got in the geo-literacy test varies 
with reference to the type of high school they had graduated from $\left[\mathrm{F}_{(3-423)}=3.655, \mathrm{p}<.05\right]$ (Table 11). In order to determine the cause of variation, multiple comparisons of the scores of students enrolled in different programs were carried out using Tukey HSD.

Table 12. Results of Tukey HSD (Post-Hoc Test) regarding the pre-service teachers' geo-literacy levels with reference to the type of high school they had graduated from

\begin{tabular}{cccc}
\hline \multirow{2}{*}{ (I) Type of High School } & (J) Type of High School & $\begin{array}{c}\text { Mean variation } \\
\text { (I-J) }\end{array}$ & Sig. \\
\hline Ordinary High School & Vocational High School & $2.22580^{*}$ & .030 \\
Anatolian High School & Vocational High School & $2.33135^{*}$ & .014 \\
& Ordinary High School & $-2.22580^{*}$ & .030 \\
Vocational High School & Anatolian High School & $-2.33135^{*}$ & .014 \\
& Other & $-2.58281^{*}$ & .016 \\
Other & Vocational High School & $2.58281^{*}$ & .016 \\
\hline
\end{tabular}

The comparisons applied with reference to the type of high school the pre-service teachers had graduated from revealed that the scores the ordinary high school, Anatolian high school, and other high school graduates got in the test were significantly different compared to the scores of their peers who had graduated from vocational high schools. This finding indicates that the vocational high school graduate pre-service teachers had lower geo-literacy levels compared to their peers who had graduated from other types of high schools, and that the type of the high school one had graduated from had an effect on the level of geo-literacy.

The results of the descriptive analysis and one-way ANOVA to show the variance, if any, in mean scores pre-service teachers got in the Geo-Literacy Test with reference to the types of settlements they had lived in during secondary education are presented in Tables 13 and 14 .

Table 13. Descriptive statistics findings regarding the pre-service teachers' geo-literacy levels with reference to the types of settlements they had lived in during secondary education

\begin{tabular}{cccccc}
\hline Settlement & $\mathrm{N}$ & Average & Std. Dev. & Min. & Max. \\
\hline Village & 74 & 11.28 & 5.50845 & 2.00 & 24.00 \\
Township & 46 & 11.82 & 4.94999 & 3.00 & 24.00 \\
District Center & 140 & 11.06 & 4.71979 & 1.00 & 21.00 \\
Province Center & 167 & 9.53 & 4.70420 & .00 & 23.00 \\
Total & 427 & 10.58 & 4.94321 & .00 & 24.00 \\
\hline
\end{tabular}

Table 13 shows that the average scores pre-service teachers got in the geo-literacy test were $\mathrm{X}=11.28$ for those who lived in villages during their secondary education, $X=11.82$ for those who lived in townships, $X=11.06$ for those who lived in district centers, and $X=9.53$ for those who lived in province centers, who also had the lowest average score among all four groups.

Table 14. One-Way anova analysis regarding the pre-service teachers' geo-literacy levels with reference to the types of settlements they had lived in during secondary education

\begin{tabular}{cccccc}
\hline Source of variance & KT & Sd & KO & F & P \\
\hline Between groups & 321.889 & 3 & 107.296 & 4.499 & .004 \\
Within groups & 10087.568 & 423 & 23.848 & & \\
Total & 10409.457 & 426 & & & \\
\hline
\end{tabular}

The variance analysis reveals that the average scores pre-service teachers got in the geo-literacy test varies with reference to the type of settlements they had lived in during secondary education $\left[\mathrm{F}_{(3-423)}=4.499, \mathrm{p}<.05\right]$ (Table 14). The results of the Tukey HSD test showing the groups which exhibit the variation are presented in Table 15. 
Table 15. Results of Tukey HSD (Post-Hoc Test) regarding the pre-service teachers' geo-literacy levels with reference to the types of settlements they had lived in during secondary education

\begin{tabular}{cccc}
\hline \multirow{2}{*}{ (I) Settlement } & (J) Settlement & $\begin{array}{c}\text { Mean variation } \\
\text { (I-J) }\end{array}$ & Sig. \\
\hline Township & Province Center & $2.28716^{*}$ & .026 \\
District Center & Province Center & $1.52536^{*}$ & .034 \\
\multirow{2}{*}{ Province Center } & Township & $-2.28716^{*}$ & .026 \\
& District Center & $-1.52536^{*}$ & .034 \\
\hline
\end{tabular}

The comparisons applied revealed significant variation in pre-service teachers' geo-literacy scores with reference to the settlements they had lived in during secondary education, between those who lived in townships and district centers on the one hand, and those who lived in province centers on the other, with the latter group scoring significantly lower. Geo-literacy levels of those who lived in townships and districts are apparently higher than those of their peers who lived in province centers. On the other hand, no significant variation was observed between the scores of those who lived in villages and the scores of their peers who lived in other types of settlements.

The results of the descriptive analysis and one-way ANOVA to show the variance, if any, in mean scores pre-service teachers got in the Geo-Literacy Test with reference to the number of provinces they had travelled to are presented in Tables 16 and 17.

Table 16. Descriptive findings regarding the pre-service teachers' geo-literacy levels with reference to the number of provinces they had travelled to

\begin{tabular}{cccccc}
\hline Number of provinces they had travelled to & $\mathrm{N}$ & Average & Std. Dev. & Min. & Max. \\
\hline $1-10$ & 264 & 10.32 & 4.75642 & .00 & 24.00 \\
$11-20$ & 112 & 10.51 & 5.20392 & .00 & 24.00 \\
$21-30$ & 25 & 11.32 & 4.59819 & 5.00 & 21.00 \\
31 or more & 21 & 13.76 & 5.02896 & 5.00 & 24.00 \\
None & 5 & 9.00 & 6.78233 & 2.00 & 19.00 \\
Total & 427 & 10.58 & 4.94321 & .00 & 24.00 \\
\hline
\end{tabular}

According to the figures provided in Table 16, the pre-service teachers who had visited 1 to 10 provinces so far got an average score of $X=10.32$ in the geo-literacy test, whereas the average score of their peers who travelled to 11 to 20 provinces is $X=10.51$, and that of the pre-service teachers who travelled to 21 to 30 provinces is $X=11.32$. Comparable figure for those who travelled to 31 or more provinces is $X=13.76$, and those who had not travelled outside their home province is $X=9.00$. Based on these figures, one can state that the higher the number of provinces visited, the higher the average score one would get in the geo-literacy test.

Table 17. One-way anova findings regarding the pre-service teachers' geo-literacy levels with reference to the number of provinces they had travelled to

\begin{tabular}{cccccc}
\hline Source of variance & KT & Sd & KO & F & P \\
\hline Between groups & 256.258 & 4 & 64.065 & & \\
Within groups & 10153.199 & 422 & 24.060 & & .032 \\
Total & 10409.457 & 426 & & & \\
\hline
\end{tabular}

The variance analysis revealed that the average scores pre-service teachers got in the geo-literacy test varies with reference to the number of provinces they had travelled to $\left[\mathrm{F}_{(3-423)}=2.663, \mathrm{p}<.05\right]$. The comparisons based on Tukey HSD analyses to reveal the causes of such variation are presented in Table 18. 
Table 18. Results of Tukey HSD (Post-Hoc Test) regarding the pre-service teachers' geo-literacy levels with reference to the number of provinces they had travelled to

\begin{tabular}{cccc}
\hline \multirow{2}{*}{ (I) Number of provinces they had travelled to } & (J) Number of provinces they had travelled to & $\begin{array}{c}\text { Mean variation } \\
\text { (I-J) }\end{array}$ & Sig. \\
\hline $1-10$ & 31 or more & $-3.43615^{*}$ & .018 \\
$11-20$ & 31 or more & $-3.24405^{*}$ & .045 \\
\multirow{2}{*}{31 or more } & $1-10$ & $3.43615^{*}$ & .018 \\
& $11-20$ & $3.24405^{*}$ & .045 \\
\hline
\end{tabular}

The comparisons revealed significant variance between the scores of pre-service teachers who had travelled to 31 or more provinces, and their peers who had visited 1 to 10 provinces or 11 to 20 provinces, with the group who had visited more than 31 provinces receiving higher scores. In the light of this observation, one can state that higher number of provinces visited would be associated with higher levels of geo-literacy.

Table 19. Geo-literacy levels of pre-service teachers

\begin{tabular}{cccccc}
\hline $\mathrm{N}$ & Series Width & Minimum score & Maximum score & $\overline{\mathrm{X}}$ & Std. Dev. \\
\hline 427 & 24 & .00 & 24 & 10.5878 & 4.94321 \\
\hline
\end{tabular}

The minimum, maximum, and average scores the pre-service teachers got in the geo-literacy test are presented in the table. The average score the pre-service teachers got is 10.5878. In the light of standard deviation, 24-19.1 range refers to a high level of geo-literacy, while 19.09-14.16 range refers to a medium level of geo-literacy, and 14.15 and less refers to a low level of geo-literacy. Based on these ranges, the average score the pre-service teachers got in the geo-literacy test -as shown in Table 19- corresponds to a low level of geo-literacy.

Descriptive data regarding the pre-service teachers' attitudes towards geography are presented in Table 20.

Table 20. The pre-service teachers' attitudes towards geography

\begin{tabular}{|c|c|c|c|c|c|c|c|c|c|c|c|c|c|c|}
\hline \multirow[t]{2}{*}{ Statements } & \multicolumn{2}{|c|}{ 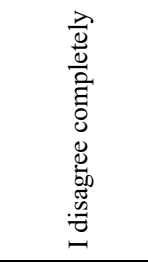 } & \multicolumn{2}{|c|}{ 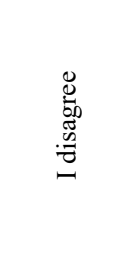 } & \multicolumn{2}{|c|}{ 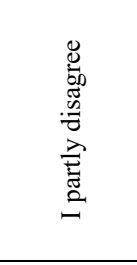 } & \multicolumn{2}{|c|}{ 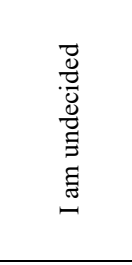 } & \multicolumn{2}{|c|}{ 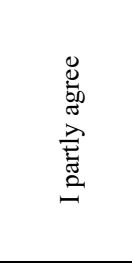 } & \multicolumn{2}{|c|}{ 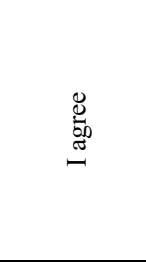 } & \multicolumn{2}{|c|}{ 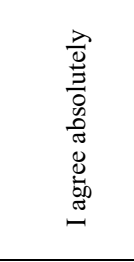 } \\
\hline & $\mathrm{F}$ & $\%$ & $\mathrm{~F}$ & $\%$ & $\mathrm{f}$ & $\%$ & $\mathrm{f}$ & $\%$ & $f$ & $\%$ & $\mathrm{f}$ & $\%$ & $\mathrm{f}$ & $\%$ \\
\hline $\begin{array}{l}\text { 1. Geography as a field is one of my } \\
\text { favorites. }\end{array}$ & 49 & 11.5 & 47 & 11 & 61 & 14.3 & 74 & 17.3 & 82 & 19.2 & 52 & 12.2 & 62 & 14.5 \\
\hline 2. I would love to teach geography classes. & 58 & 13.6 & 57 & 13.3 & 56 & 13.1 & 77 & 18 & 75 & 17.6 & 53 & 12.4 & 51 & 11.9 \\
\hline $\begin{array}{l}\text { 3. Geographic information plays an } \\
\text { important part in daily life. }\end{array}$ & 14 & 3.3 & 16 & 3.7 & 21 & 4.9 & 56 & 13.1 & 67 & 15.7 & 117 & 27.4 & 136 & 31.9 \\
\hline $\begin{array}{l}\text { 4. Geography involves interesting } \\
\text { subjects. }\end{array}$ & 57 & 13.3 & 60 & 14.1 & 78 & 18.3 & 83 & 19.4 & 62 & 14.5 & 41 & 9.6 & 46 & 10.8 \\
\hline 5. I would like to be a geography teacher. & 204 & 47.7 & 70 & 16.4 & 36 & 8.4 & 37 & 8.7 & 24 & 5.6 & 29 & 6.8 & 27 & 6.3 \\
\hline
\end{tabular}

The data presented in Table 20 above reveals that the majority of pre-service teachers believe that geography plays an important part in daily life. Approximately half of the pre-service teachers expressed interest in geography as a field, and their will to teach geography classes, albeit at various levels of interest.

Table 21. Strength of pre-service teachers' attitudes towards geography

\begin{tabular}{cccccc}
\hline N & Series Width & Minimum score & Maximum score & $\bar{X}$ & Std. Dev. \\
\hline 427 & 30 & 5 & 35 & 19.87 & 7.57248 \\
\hline
\end{tabular}


Table 21 presents the minimum, maximum, and average scores the pre-service teachers got with respect to scale items aiming to assess their attitudes towards geography. According to these figures, the average level of attitudes voiced by pre-service teachers towards geography is scored 19.87 . This figure corresponds to a level between the options "I partly agree" $(5 \times 3=15)$ and "I am undecided" $(5 \times 4=20)$. The analysis of the correlation between the scores regarding the pre-service teachers' attitudes towards geography on the one hand, and the scores they received in the geo-literacy test on the other, is summarized in Table 22.

Table 22. The relationship between the pre-service teachers' attitudes towards geography and their geo-literacy levels

\begin{tabular}{cccc}
\hline Variables & & Attitude & Literacy \\
\hline \multirow{3}{*}{ Attitude } & $\mathrm{r}$ & 1 & $.380^{* *}$ \\
& $\mathrm{p}$ &. & .000 \\
& $\mathrm{~N}$ & 427 & 427 \\
\hline \multirow{3}{*}{ Literacy } & $\mathrm{r}$ & $.380^{* *}$ & 1 \\
& $\mathrm{p}$ & .000 &. \\
& $\mathrm{~N}$ & 427 & 427 \\
\hline
\end{tabular}

**. The correlation is significant $(\mathrm{p}<.01)$.

Despite the lack of universal agreement regarding the ranges to be used in the interpretation of correlation factors, previous studies often considered $0.00-0.30$ range to be low, $0.30-0.70$ range to be medium, and $0.70-1.00$ to be high in terms of correlation levels (Büyüköztürk, 2002, p. 32). According to Table 22, the correlation factor is $r$ $=0.380$, whereas the significance level is $\mathrm{p}=0.00$. Based on these figures the correlation between the attitudes towards geography and the levels of geo-literacy can be considered a positive and significant one, at medium level of strength. In the light of this result, one can forcefully argue that stronger attitudes towards geography lead to increased geo-literacy levels at a medium level. A glance at the determination factor $\left(\mathrm{r}^{2}=0.14\right)$ reveals that $14 \%$ of the geo-literacy score is associated with positive attitudes towards geography.

\section{Conclusions and Discussion}

Findings reached with respect to the fundamental problem investigated in this study reveal that the pre-service teachers' geo-literacy levels are inadequate. In particular, the findings regarding locating skills show that the pre-service teachers' ability to locate Turkey's neighbors on a sketch map can be considered inadequate. Moreover, pre-service Primary School, Mathematics and Turkish teachers had stronger locating skills compared to other programs, while the pre-service teachers in the Preschool Teacher Training program stood out with the lowest scores in this respect. A wide range of factors may have contributed to this result, which can be labeled geographic ignorance, and which runs parallel to the findings of other studies. The literature points at a large number of factors affecting geo-literacy, and reveals that the concept is much more complicated than what initial impressions would suggest. Thus, trying to explain geographic information and geo-literacy levels with a single reason would not be a supportable position. Against this background, activities focusing on practice through the education process can arguably help with increasing geo-literacy levels in general and the development of map and location skills in particular. Such practices, in turn, require adequate numbers and hours of geography classes at the primary and secondary school levels. In the same vein, existing studies note that, in the US, Canada, and Australia, teachers' geography education levels remain inadequate due to the replacement of geography classes with social studies ones, and that the teachers of the future lack geo-literacy skills (Chiodo, 1993; Eve et al., 1994). In a similar debate, the coverage of geography topics in social studies classes rather than dedicated geography classes in primary education settings is noted as the reason of ignorance about geography. The inclusion of geography as an independent element of curricula is proposed as a solution to this problem (Bennet, 1997, 13). One can also argue that the limited coverage provided to geography topics in social studies courses in Turkey also played a part in this result.

Similar conclusions were reached in other studies concerning geo-literacy. From time to time, the National Geography Agency of the US procured geo-literacy studies from Roper research corporation. One such study involving a sample of 510 individuals revealed that approximately half (46\%) of young adults in 18-24 age group did not have adequate geographic information. One of the most striking results was that in March 2003, which marked the invasion of Iraq by the US, $63 \%$ of the participants in the study failed to locate Iraq on a map. It was also found that $75 \%$ of the participants were ignorant about the location of Indonesia, which was recently hit by a 
severe tsunami (National Geographic Roper Survey, 2002; National Geographic Roper Survey, 2006). Another study on the topic was carried out by Cross (1987), who found, with a sample of 879 college students who took courses on the geography of the regions of the world and on cultural geography, that the students' basic geographic skills were simply inadequate. Cross reached this result based on data derived from a survey asking the participants to point the location, state the latitudes and longitudes, and name major rivers of 11 countries (including China, Cuba, the UK, Soviet Union, Iran, and India) which were involved in current issues of the day. Other studies also reached similar conclusions (Bein, 1990, 2009; Bunnin, 2001; Cross, 1987; Chiodo, 1993; Donovan, 1993; Eve et al., 1994; Gencturk, 2009; Hardwick et al., 2000; NAEP, 1994; Nolan, 2002; Oigara, 2006; Roger, 1997; National Geographic Roper Survey, 2002; National Geographic Roper Survey, 2006; Saarinen \& MacCabe, 1995; Sievertson, 2005; Thomas, 2001; Torrens, 2001; Tuncel, 2002; Winship, 2004; Wood et al., 1988).

Yet another conclusion reached in the present study is that the geo-literacy levels of male pre-service teachers were higher compared to their female peers. Hence the finding that gender is an important variable affecting geo-literacy levels, which is consistent with those of other studies in the literature. Almost all studies on geo-literacy noted significant differences associated with gender, with males performing better in terms of geographic information and spatial skills compared to females (Bein, 1990; Cross, 1987; Chiodo, 1993; Eve et al., 1994; Genctürk, 2009; Hardwick et al., 2000; NAEP, 1994; National Geographic Roper Survey, 2002; National Geographic Roper Survey, 2006; Nolan, 2002; Oigara, 2006; Thomas, 2001; Torrens, 2001; Wood et al., 1988; Winship, 2004). This finding may be a result of the prevailing culture of the society, as well as the perceived higher levels of interest men have in the external world and the environment. Other studies on gender, carried out by psychologists and geographers, also noted certain gender-based differences in terms of geographic and spatial knowledge (Kitchin, 1996). Even though a number of theories exist to explain such differences, the one with the widest level of acceptance among geographers is the differences theory. According to this theory, socio-cultural structures, institutional and social expectations, preschool education, and established perspectives all play some part in bringing about such differences (Kitchin 1996).

Thus, with the effect of various socio-cultural structures and environmental factors, gender imposes different personal characteristics and social roles on girls and boys (Hardwick et al., 2000; Rose, 1993, quoted by Kitchin, 1996). Gender is shaped by the social environment, alongside its innate aspects. The literature points at the different cognitive styles expressed by boys and girls, not to mention the differences in their biological features, along with the different socialization processes they go through, as the root cause. A number of theories try to explain why gender leads to differences. One such theory-the deficiency theory-claims that human psychology and differences in hormones are what leads to the differences in question. According to this theory, all spatial skills and competences can be explained with reference to the genetic structure and the different amounts of estrogen and androgen present in human body (McGee, 1979; quoted by Kitchin, 1996). Another theory argues that socio-cultural factors such as education in preschool years, the expectations of the family and the school, and established conventions are the primary determinants. The most popular theory regarding the effect of the control of the brain on gender-related issues with respect to spatial skills is the lateralization theory. This theory, in turn, argues that spatial skills are associated more with the use of the right hemisphere of the brain, and that men have better spatial skills as they use the right hemisphere more compared to women (Bowers \& LaBarba, 1988, quoted by Kitchin, 1996).

Yet another finding reached in the present study is that the type of high school the pre-service teachers had graduated from affected their average scores. The geo-literacy scores of pre-service teachers who graduated from vocational high schools were found to be significantly lower than those of their peers who graduated from other types of high schools. The increased weight of vocational courses in the curriculum of vocational high schools, while general culture courses such as history and geography are provided only limited hours may help explain this result. That is why students who graduate from these schools exhibit lower levels of geographic information compared to their peers who graduated from other types of high schools. On this point Winship (2004) noted no significant difference between those who took just one geography course and those who took none, but proceeded to add that a significant difference existed between those who took two geography courses and those who took none.

With reference to the effect the individuals' geographic habitat has on learning, the present study investigated whether the type of the settlement the students lived in during their preceding years had an effect. The average geo-literacy scores of those who lived in smaller settlements (townships and district centers) prior to their university years were found to be higher than their peers who grew up in province centers. Indeed Cin and Yazic1 (2002) and Cin $(1999,2008)$ showed the major part played by the interaction children had with the geographic environment they live in, as the source of knowledge they came to have about the geographic environment. In the 
same vein, NAEP (1994) observed that the type of settlement the 4th and 8th grade students live in had different effects on their geographic knowledge. It is noted in this context that the geographic knowledge levels expressed by those who live in a city were lower than those expressed by village- (with a population in 2,500-25,000 range) or suburb-dwellers. Oigara (2006), in turn, found that those who live in outskirts of the city had higher geography scores in all three ranges (low, medium, high). The scores of those who live in big cities such as New York, on the other hand, were found to be lower.

Studies on geo-literacy mention travel experience as another important variable. The present study also found that the domestic travel experiences of pre-service teachers had an effect on their geo-literacy levels. Cross (1987) and Eve et al. (1994) did not note a significant relationship between travel experience and geo-literacy, whereas Bein (1990) and Winship (2004) reached to the conclusion that travel was important in terms of gaining the ability to interpret geo-literacy. On the other hand, Nolan (2002) stated, in contrast to other studies, that travel experience, taken into account with the characteristics of formal education, contributed significantly to the geo-literacy skill. Oigara (2006) observed that those who had so far travelled to a higher number of states or countries received higher average scores.

It is well known that the attitudes the students have with respect to a specific course affect their performance in that course. The present study also found that the pre-service teachers who had positive attitudes towards geography had higher geo-literacy levels. This finding is consistent with those of other studies in the literature. Yau (1977) underlined the importance of attitudes in building up geographical awareness. Sack and Peterson (1998) note a strong association between attitudes towards geography and geographic knowledge. That is why teachers play an important part in raising students with geo-literacy, and should try and organize activities to raise interest about geography among their students. Bein (1990) also reached similar conclusions, and noted that students with positive attitudes towards geography had better geography skills. Oigara (2006), in turn, stated that positive attitudes towards geography played an important part in terms of determining geographic knowledge levels, before proceeding to point at the strong association between attitudes and geo-literacy, and adding that people who are interested in geography had higher geo-literacy levels.

\section{References}

Anderson, C. A., Gentile, D. A., \& Buckley, K. E. (2007). Violent video game effects on children and adolescents: Theory, research, and public policy. Oxford University Press. https://doi.org/10.1093/acprof:oso/9780195309836.001.0001

Balcı, A. (2001). Sosyal Bilimlerde Araştırma Yöntem, Teknik ve İlkeler. Ankara. Pegem A Yayıncılık

Bein, F. L. (1990). Baseline geography competency test: Administered in Indiana Universities. Journal of Geography, 89(6), 260-266. https://doi.org/10.1080/00221349008979213

Bein, F. L., Hayes, J. J., \& Jones, T. G. (2009). Fifteen year follow-up geography skills test administered in Indiana, 1987 and 2002. Journal of Geography, 108(1), 30-36. https://doi.org/10.1080/00221340902886798

Bennett, M. W. (1997). Development of Geographic Literacy in Students with Learning Disabilities.

Bernstein, T. M. (1965). The careful writer: A modern guide to English usage (2nd ed.). New York, NY: Atheneum.

Bjork, R. A. (1989). Retrieval inhibition as an adaptive mechanism in human memory. In H. L. Roediger III, \& F. I. M. Craik (Eds.), Varieties of memory\&consciousness (pp. 309-330). Hillsdale, NJ: Erlbaum.

Bunin, C. (2001). A study of the relationship between current event knowledge and the ability to construct a mental map of the world (Master's thesis, Virginia Polytechnic Institute and State University). Retrieved from http://scholar.lib.vt.edu/theses/available/etd-01242001-123819/

Chapin, J. R. (2009). Elementary Social Studies. A Practical Guide (7th ed.). United States. Allyn and Bacon.

Chiodo, J. J. (1993). Mental maps: Preservice teachers' awareness of the world. Journal of Geography, 92(3), 110-117. https://doi.org/10.1080/00221349308979633

Cin, M. (1999). The Influence of Direct Experience of the Physical Environment on Concept Learning in Physical Geography (E.D Thesis, School of Education, University of Durham).

Cin, M. (2008). Sınıf öğretmeni adaylarının yaşadıkları yere göre coğrafya dersine karşı tutumlarındaki Farklılıklar. Kastamonu Eğitim Dergisi, 16(1), 185-190.

Cin, M., \& Yazıc1, H. (2002). The influence of direct experience experience on children's ideas about the formation of natural scenery. International Research in Geographical and Environmental Education, 11(1), 


\section{5-14. https://doi.org/10.1080/10382040208667459}

Cohen, L., Manion, L., \& Morrison, K. (2007). Research Methods in Education (6th ed.). Routledge, London, Taylor \& Francis Group. https://doi.org/10.4324/9780203029053

Creswell, J. W. (2003). Research Design: Qualitative, Quantitative, and Mixed Methods Approaches (2nd ed.). SAGE Publications. London, Thousand Oaks, New Delhi.

Cross, J. A. (1987). Factors associated with students' place location knowledge. Journal of Geography, March-April, 59-63. https://doi.org/10.1080/00221348708979457

Doğanay, H. (2002). Coğrafya Öğretim Yöntemleri. 5. Baskı. İstanbul. Aktif Yayınevi.

Donovan, I. (1993). Geographic literacy and ignorance: A survey of Dublin adults and school children. Geographical Viewpoint, 21, 73-92. https://doi.org/10.1038/021073a0

Eve, R. A., Price, B., \& Counts, M. (1994). Geographic iliteracy among college students. Youth Society, 25(3), 408-427. https://doi.org/10.1177/0044118X94025003006

Gençtürk, E. (2009). İlköğretim sosyal bilgiler öğretmen adaylarının coğrafya okuryazarlı düzeylerinin belirlenmesi (Unpublished PhD thesis). Gazi University Institute of Educational Science, Ankara

Gray, D. E. (2004). Doing Research in the Real World. SAGE Publications. London.

Gritzner, C. F. (2002). What is where, why there, and why care? Journal of Geography, 101(1), 38-40. https://doi.org/10.1080/00221340208978465

Hardwick, S. W., Bean, L. L., Alexander, K. A., \& Shelley, F. M. (2000). Gender vs. sex differences:factors affecting performance in geographic education. Journal of Geography, 99(6), 238-244. https://doi.org/10.1080/00221340008978974

Hutchinson, S. R (2004). Survey Research. In K. D Marrais, \& S. D. Lapan. (Eds.), Foundation for Research Methods of Inquiry in Education and the Social Sciences. Lawrence Erlbaum Associates Publishers. London.

Karabağ, S. (2001). Coğrafya öğretiminde anahtar sorular ve kavramlar. G.Ü. Gazi Eğitim Fakültesi Dergisi, $18(2), 25-41$.

Karabağ, S., \& Şahin, S. (2007). Coğrafya Dersi Öğretim Programı (pp. 55-74, 2005). In S. Karabăg, \& S. Şahin (Eds.), Kuram ve Uygulamada Coğrafya Ĕgitimi. Ankara. Gazi Kitabevi.

Karasar, N. (1998). Bilimsel Araştırma Yöntemi. Nobel Yayın Dă̆ııım. Ankara.

Kitchin, R. M. (1996). Are there differences in geographic knowledge and understanding. The Geographical Journal, 162(3), 273-286. https://doi.org/10.2307/3059650

Marran, J. F. (1992). The world according to a grade 12 teacher reflections on what students of geography should know and be able to do. Journal of Geography, 91, 139-142. https://doi.org/10.1080/00221349208979501

National Education Process (NAEP, 1994). Geography Report Card. National Assessment of Educational Progress, Princeton, Washington DC.

National Geographic Roper. (2002). Global Geographic Literacy Survey. Prepared by RoperASW for: National Geographic Education Foundation. Washington D.C.

National Geographic Roper Public Affairs (2006). 2006 Geographic Literacy Prepared by RoperASW for: National Geographic Education Foundation. Washington D.C.

Nolan, R. E. (2002). Geo-literacy: How well adults understand the world in which they live. Adult Basic Education, 12(3), 134-144.

Oigara, J. (2006). A multi-method study of background experiences influencing levels of geographic Literacy (Ph.D. thesis, Binghamton University, USA).

Rogers, L. (1997). An examination of elementary teachers' knowledge of geography and geographic education (Phd.Dissertation, Binghamton University, New York).

Saarinen, T. F., \& MacCabe, C. L. (1994). World patterns of geographic literacy based on sketch map quality. Professional Geographers, 47(2), 196-204. https://doi.org/10.1111/j.0033-0124.1995.00196.x

Sack, D., \& Petersen, J. F. (1998). Children's attitudes toward geography: A Texas case study. Journal of Geography, 97(3), 123-131. https://doi.org/10.1080/00221349808978836 
Şahin, S. (2003). Coğrafya öğretiminde beş temel konu. 15-18 Ekim 2003 XII. Eğitim Bilimleri Kongresi, Antalya.

Schoenfeldt, M. (2001). Geographic literacy and young learners. The Educational Forum, 66, 26-31. https://doi.org/10.1080/00131720108984796

Sievertson, M. D. (2005). Is geography knowledge improving? A study of current geographic knowledge among united states college geography students (Phd. dissertation, Delta State University, Cleveland, Mississippi).

Thomas, P. G. (2001). An analysis of the geographic knowledge of preservice teachers at selected midwestern Universities (Ph.D Thesis, Kansas State University, USA).

Thomas, P. G. (2001). An analysis of the geographic knowledge of preservice teachers at selected Midwestern Universities (Ph.D thesis, Kansas State University, USA).

Torrens, P. M. (2001). Where in the world? Exploring the factors driving place location knowledge among Secondary level students in Dublin, Ireland. Journal of Geography, 100(2), 49-60. https://doi.org/10.1080/00221340108978417

Trygestad, J. (1997). Students' conceptual thinking in geography (Ph.D thesis, University of Minnesota, USA).

Tuncel, H. (2002). Türk öğrencilerin zihin haritalarında islam ülkeleri. Firat Üniversitesi Sosyal Bilimler Dergisi, 12(2), 83-103.

Winship, J. M. (2004). Geographic literacy and world knowledge among undergraduate college students (Master of Science in Geography, Virginia Polytechnic Institute and State University, USA).

Wood, W. R., Eicher, C., Webster, L., \& Gullickson, A. (1988). Geographical knowledge of university elementary education majors. Report The University of South Dakota.

Yau, B. L. L. (1977). Social attitudes and the teaching of geography. Educational Journal, No. IV.

\section{Copyrights}

Copyright for this article is retained by the author(s), with first publication rights granted to the journal.

This is an open-access article distributed under the terms and conditions of the Creative Commons Attribution license (http://creativecommons.org/licenses/by/4.0/). 